\title{
THE ROLE OF HUMAN RESOURCE IN ORGANIZATIONAL PERFORMANCE IN THE AUTOMOTIVE INDUSTRY
}

\author{
Endre Szabó, Katinka Bajkai-Tóth, Ildikó Rudnák, Róbert Magda \\ Hungarian University of Agriculture and Life Sciences
}

\begin{abstract}
In the course of the research, we examined the impact of the selection and training system of a Hungarian automotive company on organizational performance, which together ensure the future development of the company. It contributes to the optimization of sales, purchasing and logistics processes, ensures customer satisfaction and the success of the company. In this fast-paced and globalized world, it is essential for companies to be aware that one of the most important factors of production is human resources themselves, whose proper selection and training are a key element in maintaining and developing economic competitiveness. Human resources play the biggest role in the operation of an economic organization. Process quality and process orientation reduce costs, increase profitability, and improve processes to always meet growing requirements. This is the basis of the quality strategy. Therefore, it consistently applies preventive quality assurance methods, learns from failures, eliminates the causes of mistakes without delays and transfers its experience to all areas of the company for preventive action. It is customer-oriented and strives for excellence in all areas, and thus makes it an obligation for everyone to aim for the highest level of customer service. Due to the special peculiarities and characteristics of the labor force, it cannot be compared to any of the production resources. Taking this as a basis, the human resource management used to be more of a functional purpose, while in recent decades human factors have become an essential source of competitiveness. The market operation and performance of an organization depends significantly on how we can select the most suitable workforce. We need to see what the strategic points that determine the role of $\mathrm{HR}$ are, and we are also looking for the answer in which direction the needs, expectations and professionalism given by the generational difference move the activities of human resources. The aim of the research is to get an answer to how the employees of one of the leading Hungarian players in the automotive industry perceive the importance of the selection and training of the workforce in maintaining and improving competitiveness. To this end, we used a semi-structured interview, with the help of which we evaluated the current selection and training processes in the light of competitiveness and made suggestions for the improvement and refinement of these processes.

KEY WORDS: competitiveness; optimization; training; selection; quality.
\end{abstract}

JEL classification: $\mathrm{O} 10, \mathrm{O} 15$

\section{Introduction}

Human resources are one of the most important elements of an organization and have a major impact on organizational performance. Human resources for sustainable competitive advantage sources and development promises to significantly improve business performance. We are able to manage human resources, ensure the effective training and retraining of available human capital to meet the conditions of competitiveness. In order to be able to respond to constant economic change, companies must place a great emphasis on the selection and training of their workforce. It is almost essential to use these economic tools to the highest possible degree in the economic life of the single organizations. In our opinion, investing in human resources within the firms is a crucial factor in maintaining competitiveness and should become a future strategic goal for companies.

Human resources are the only resources that can be renewed. It is not part of equity, it cannot be sold, but its capacity and competencies significantly affect the value of the company (Beardwell and Holden 1994). One of the main activities of HR, employee retraining and further training as an investment in human capital, is an important component of the corporate strategy, thus contributing to the achievement of business objectives. In addition, it has a positive effect on the direct (employee and employer) and indirect (labor market, vocational training institutions and teachers, professional bodies) of the enterprise. Effective strategic thinking emphasizes the need to secure, manage, and motivate human resources (Becker and Huselid 2006). The quality, efficient use, and development of this resource in knowledge-based organizations is of particular importance, as it is the only way for them to make full use of their technological capabilities and gain a competitive advantage in the market (Gooderham and Nordhaug 2010). Human resource management attaches great importance to communication, the conscious development of organizational culture, and the commitment of employees to the identification of tasks. After all, maximum performance can only be expected if the goals of the company and the individual meet and they come into effect. Employees should be seen as investments in human capital that can be achieved through continuous training and development, efficiency gains at the organizational level (Cohen and Prusa 2001). People as resources mean much more than the size and education of the workforce. They mean, among other things, people's values, work ethic, commitment to the company, relationships, and creativity (Csath 2004).

In the last decade, the role of human resources in the economy has significantly increased as a result of technological and social developments. The importance of strategic thinking is emphasized by the provision, 
management and motivation of human resources. The quality, efficient use and development of this resource in innovative, knowledge-based organizations is of particular importance (Poór et al. 2012). All of this is done so that companies can leverage their technological capabilities and gain a competitive advantage in the marketplace. The highest performance can be expected when the goals of the organization and the individual are in harmony. Modern organizations are obsessed with innovation. It seems that a collaboration-oriented managerial environment helps to find a balance between the interests of the organization, represented by innovation, and, on the other hand, the interests of employees, represented by the degree of their satisfaction (Borisov and Vinogradov 2020). The efficient use of human resources is facilitated by the personnel functions used in management, while individual and organizational goals are also considered (Brewster 2002). A close link must be established between these goals and aspirations. One of the most sensitive areas for corporate governance is human resource management. One of the most important characteristics of a human resource is that it has an independent, free will through which it can regulate its actions and, consequently, its performance (Schuler 2000). In addition, the company must have a clear view of the following aspects. Human resources have a given capacity and supply of power, they are acquired through the market, and their price is influenced by supply and demand conditions (De Silva 1997). The performance of human resources is maintained in the long run, and even through appropriate development programs and learning, their performance can be increased. The only resource that can be renewed (Bratton and Gold 1994). Developing the right motivation for human resources is a key part of the strategy. The organizational structure and system of the company are closely related to the human resource management strategy. As the developed strategy will be implemented in the context of organizational culture, it is important to clarify what the company's values, traditions and customs are (Chikán 2017).

\section{Literature review}

\section{Human Resource Management}

Human resource management solutions implemented in specific organizations in many countries are greatly influenced by historical background. The broader role of HRM is to provide a human resource of adequately trained, motivated and efficient employees to reach the objectives of the organization (Purcell et al. 2003). One of the core long-term goals of organizations is to ensure survival and growth. Companies strive for efficiency in a goal-oriented manner. This goal is pursued with the consent of the people, so taking into account the needs and goals of human capital is an important task. In intellectual capital, human capital has an essential meaning and its efficiency also depends on the perceived quality of life (Szewczak and Wozniak 2019).

The content of human resource goals may, of course, vary from organization to organization, but generally includes the following principles:
- Quality product

- High performance

- Controlled labor costs

- Competitive wages

- Low levels of fluctuation and absence

- Adequate working conditions that ensure employee job satisfaction and the opportunity for self-assessment

- Employing an adequate number of employees with the desired expertise and experience

- Compliance with laws and regulations, ensuring working conditions and workers' rights

The aims of HR move on a wide scale, from working in harmony with each other to serve a common goal. They promote the long-term success and competitiveness of the organization (Gooderham and Nordhaug 2010).

To do this, it is important to prioritize the following goals:

- Provide well-trained, well-motivated employees for the organization (Choi and Rainey 2013)

- Apply the skills and abilities of the workforce effectively

- To ensure the satisfaction and self-realization of employees as much as possible

- Communicate personnel policies and policies to the employee

- Help maintain ethical principles and practical behavior (Agu and Fekete-Farkas 2016)

- Manage change in a way that is mutually beneficial to individuals, groups, the company and the wider community

- Maintain and improve the quality of work in such a way as to make it desirable to have employees within the organization (Brewster 2007)

Selection

Labor demand, market supply and demand are the cornerstones of human resource management processes such as selection and corporate training based on it. The selection process is generated by a need. Labor demand is created by several factors:

- company development, expansion

- job vacancies

- new, state-of-the-art technology that requires a new, more skilled employee

It is therefore important to see the reasons for the need and to formulate the goals based on it.

- For what purpose is new workforce needed?

- Did the labor demand derive from within or outside the company?

When it comes to hiring new staff, the first step is for an organization to decide whether it wants to address the need for manpower through redeployment within the company or whether it wants to hire a new employee outside the company. This is one of the key issues in 
selection that is strategically crucial. The direction will be what management formulates in its long-term plans for the employment of the workforce (Poór 2013). It will adapt to corporate culture and adapt to market conditions and risks. Organizations often fill jobs by reallocating their own internal resources. This benefits the organization because it allows you to fill the job with a dedicated person who knows how the organization works, and it helps you accomplish the desired performance faster. It is also beneficial for the employee, because it usually means progress in their career, as it involves training, development and provides opportunities for selfrealization (Chang and Huang 2005). In the case of external recruitment, appropriate methods are needed to locate and choose candidates. Various selection methods, tests and interviews are used to select the right candidate.

However, the suitability and effectiveness of these selection methods also need to be examined (Gooderham and Nordhaug 2010). Which option a company chooses is mostly a function of market factors. It can be traced back to the issue of risk management, cost-effectiveness. The redeployment of the workforce within the company is essentially based on the retraining and development of the existing workforce. In the study, we place more emphasis on selection outside the corporation. We believe that more interesting, more complex issues from a corporate strategic point of view are raised by recruiting from outside.

Selection, as a functional activity of HRM, reflects the human strategy and policy of the management (Arthur 1994). The first step in selection is recruitment, which can begin the selection process itself. Recruitment and selection among human resource management activities is a critical point because the right amount and composition of the workforce is able to implement the strategies and plans developed by companies (Collis and Montgomery 2008).

The choice is absolutely in the hands of the human class. The goal of the selection process is to find the most suitable candidate for the job that best fits the needs of the company (Glaister 2014) In addition to the general attractiveness advertised, labor recruitment is highly dependent on labor market conditions. If there is oversupply in the labor market, the company usually has to make an effort to get the labor force, while in case of oversupply, you can expect employees to look for a company directly. The methods can be varied and versatile:

- employment centers

- consulting companies

- temporary employment agencies

- job fairs

- tenders, advertisements

The choice is absolutely in the hands of the human resources department. It is advisable to choose several methods and advertising areas, to combine them. After all, according to the law of large numbers, the more people are informed about opportunities, the more people will be interested and apply.
Based on this, the company can choose from a larger number of employees, and a larger number increases the chances of finding the most suitable people to fill the advertised positions. This process is an extremely difficult task for selecting staff, as they have a short time to get to know and evaluate the candidate, as well as to make a decision that will be appropriate in all respects for the future of the company ( Lawler and Boudreau 2018)

Parts of the selection process

- Application management

The received applications are subject to database registration and all candidates will be notified by post. Registered applications will be evaluated by the search officers and decided according to the requirements profile of the vacancies, which applications will be forwarded to the managers.

- Interview

If the leader would like to have a recruitment interview with the candidate, a notification will be sent by e-mail to the human resources department with three possible interview dates. The interview will be organized with the department that reported back the earliest, but if interested, two more classes can participate in the admission interview. The first feedback department has the opportunity to bid on the contract for the first time. If more than one department is interested, the candidate can decide which position offered they are most interested in. The recruitment interview will be documented and evaluated.

- Decision on admission

After conducting the recruitment interviews, the manager and the staff officer will decide which candidate to bid on. Prior to making the offer, the Human Resources Department will perform an audit of the candidate to be hired in accordance with the Central Internal Audit Standards. If the candidate is not on the terrorist register, a printed file must be attached to the application file. If he is on the register, the candidate must be rejected. The same rules apply to the selection of seconded staff as well as trainees. The contract offer is then prepared and made by the human resources department to the candidates after consultation with the supervisor. If the offer is accepted, the candidate will take part in a medical aptitude test and then take up the job at the agreed time (Hodges 2017).

\section{Training}

Today, we are witnessing global changes that are forcing companies to adapt to change, or demand to change themselves. All this has a significant impact on human resource development. The development of communication and the improvement of analytical and decision-making skills become of great importance. To meet the challenge of companies, consciously structured training programs are needed. Due to the globalization of business, there has been an increased need for access to expertise anywhere (Adler and Ghadar 1990). In order for a company to be successful in this environment as well, 
its educational programs must provide an opportunity for its employees to learn materials that are relevant to their position, even on the go. The global economy requires well-trained employees, corporate tasks are becoming increasingly complex, and employees thus need welldefined education.

The totality of training needs at the level of individuals and groups represents the development needs of the organization. Recently, it has been found among employees that their expectations for improving the quality of life and deepening the content of work have increased (Boxall and Purcell 2000). The way to comply with this is often relocation within the organization and there is a need for training if it is not the job that changes, but a new job according to the individual's desire to grow. The training needs of the groups stem from the direction of organizational strategy and the need for cultural change. The main factors that trigger the training may be:

- intensifying competition in both domestic and international markets

- acceleration in technological change and automation

- changes in the nature of the workforce

- time spent on management activities is reduced

- change of ownership, mergers, profile change

As companies adapt to changes in the environment, they create training systems to help their employees in the process of adaptation. The purpose of the training is for the individual to meet the current or future requirements of the organization and to be able to do their job effectively.

The most common training goals are:

- improving quality

- increasing in productivity

- preparing for the introduction of new technology

- increasing organizational flexibility

- increasing job satisfaction

- transforming the organizational culture

- reducing accidents at work

- minimizing costs

The goals of the training basically indicate two directions:

- they want to prepare employees for the future

- $\quad$ skills gaps are to be addressed

The money spent on development in an organization should not be interpreted as a cost but as an investment in human resources. This approach is no longer uncommon to companies in developed industrial countries (Gmür and Thommen 2007).

\section{Parts of the training process}

For the company, the qualifications of their employees ensure competitiveness. That is why further training, careful information and the integration of workers are of great importance. In line with the company's traditions and goals, it pays great attention to the development and training of its employees. Accordingly, its training guidelines for the corporate vision are as follows:
- The successful operation of a company depends on the qualifications and motivation of its employees.

- Professional qualifications and the associated responsibilities play a significant role in motivating employees in addition to pay.

- In addition to the ability of employees to perform, the tools used in education and training also make a significant contribution to the development of performance-enhancing skills.

- In-company training supports employees and departments, helping them to perform their current and future tasks effectively.

- In an ever-changing environment, they support the learning ability of their employees and develop their ability to act.

- The focus is on the client: they compile their training offer according to the constantly articulated needs, and they provide quality service through training counseling and continuous development of training programs, where it is especially important to transfer what has been learned into everyday work. The goals of the professional trainings are formulated by the company.

The following objectives are considered when assessing and planning training needs:

- Responsible and cooperative work

- Improving the quality

- Increasing customer orientation

- Optimizing process

- Reducing the cost of products and services

- Increasing the competitiveness of the company

The training demand is assessed and planned on the basis of a standard training matrix defined by the head of the department, defined for the areas of activity.

New employees entering administrative positions are placed in the given job on the basis of a "Training Plan" prepared by their supervisor. A copy of this shall be sent to the personnel department after completion for documentation in its personnel file.

The planning of further training should be carried out in the framework of employee interviews held once a year. Then, both the manager and the employee can live up to their suggestions. Following an agreement between the manager and the employee, the following situations may arise:

- The employee participates in the training to be held within the organization, enrollment in the course is done by the training department at the direction of the leader.

- The employee participates in external training, enrollment in the course is done by the department secretariat or the personnel department at the direction of the manager. 
Conditions for the effectiveness of training

The efficiency of the trainings is a primary aspect for the companies, as they spend a lot of money on educating the employees and improving their knowledge.

\section{Training is effective if:}

- Fits in properly: Fits into the organization's human resources policy.

- Based on strategic considerations: Takes into account what skills the organization will be able to employ in the future.

- Relevant: Only the satisfaction of real needs is taken into account when determining the method and theme of the training.

- Problem-centric: Focuses on where there are gaps in knowledge or skills that do not allow for effective work.

- Activity- and result-oriented: By this we mean that when setting goals, we need to define how the participants in the training can utilize the acquired knowledge during the work processes.

- Performance-centric: This means that the performance improvement resulting from the training can be identified and measured.

- Continuous: We do not mean a one-time action, but a continuous process (Brewster et al. 2010).

\section{Competitiveness}

The competitiveness of firms is nothing more than the result of being able to develop and maintain special competitive advantages that are different from others. The basic question of competitiveness management is how the company chooses the racing track on which the company wants to compete (Chikán and Czakó 2009). This decision is made by examining two main groups of factors. One is what the company's capabilities and resources make possible. The other factor is the value system, philosophy and approach of the company's management. The key factor is for the company to create more value for its customers than its competitors, which really matters how efficiently and innovatively it utilizes its resources (Wolff et al 2007). Nowadays, the human sector is playing an increasingly important role in maintaining competitiveness. His responsibilities may include knowledge management, the establishment and operation of corporate universities, building an organizational culture, and strengthening social capital within the company. Through its activities, it creates value and improves the company's competitiveness. The human function as a whole must be emphasized, it must be part of the strategy-making and implementation processes (Aiginger and Landesmann 2002). The contribution of human resource management to competitiveness covers several areas:

- Globalization: Globalization means new market opportunities, new products, new ideas, new methods and new competitors for companies. Global knowledge is needed to track rapid change.
Without an excellent team of professionals and a flexible organization, implementation is unthinkable. Creating this requires effective human resource management work.

- Changing value chain: The value chain shows what values are generated and what costs are incurred within the company. Buyers are interested in getting as much value as possible as cheaply as possible. Companies therefore need to strengthen their customer orientation. The effective operation of human resource management is an important element of the value chain, supporting value creation, therefore its activities must also cover customers and suppliers. Its job is to ensure the smooth operation of connections within networks from a human perspective.

- Increase profits: Lasting success requires constant innovation, renewal, change and the search for new markets. All of this can only be successful in the right atmosphere, with the involvement and active participation of employees (Gallie and Zhou 2013)

- Organizational skills: Organizational skills are vital elements of competitiveness. These are the characteristics that set a company apart from its competitors. HR professionals play an important role in developing organizational skills. In addition to developing the individual skills of employees, they also need to find a way to turn those skills into organizational team skills.

- Change: Change needs to be managed as its success depends on the active participation of HR professionals. Strategic actions, good decisions made in time are the key issues for change.

- Technology: The rapid spread of technological advances is aided by newer advances in information technology that allow for the rapid flow of information. Technological results facilitate the work of human resource management.

- Acquisition and retention of professionals: Excellent professionals are the most important conditions for competitiveness, therefore the strategic task of human resource management is to acquire and retain them. Companies will need people who are team players, dare to take risks, are good problem recognizers and solvers (Feurer and Chaharbaghi 1994).

The HR field requires a high level of professional work, which at the same time relies on a sound theoretical foundation and practical experience. The impact of its work on company results can be measured, the most important of his tasks is value creation and increasing the company's intelligence capital. It is important to provoke debate in the greatest possible ways, thus contributing to the improvement of competitiveness, and to develop practices that can help a company become more competitive due to its employees (Csath 2010). 


\section{Research Methodology}

The following research methods were applied: a scientific literature review, interview, comparative data analysis. The interviews were carried out with $25 \mathrm{HR}$ experts from 30 March 2020 until 31 July 2020. The participation in the interview was based on the principle of volunteering and confidentiality.

The purpose of the research is to present the selection and training program of one of the key players in the Hungarian automotive industry and examine their role in organizational performance. Selection and training are essential to maintain long-term competitiveness, so the study focuses on analyzing these issues:

1. Where are jobseekers most likely to find out about the latest vacancies?

With the rise of the internet, online platforms are becoming increasingly popular. Today, the majority of job advertisements are found almost first-hand on job portals. Most advertise their open positions on these platforms. The current viral situation has also pushed businesses and workers online, into the digital world, which confirms that online platforms are the most popular today, and the first place where jobseekers look for information. The Internet makes job search quick, easy and accessible from anywhere.

2. In job advertisements, will the name of the advertised position be the first factor that gets the most clicks on online platforms?

In this area, the main focus is on jobs advertised online, which is one of the most popular job search channels, according to the survey. It is assumed that an advertisement will be clicked on if the job title in the advertisement is one that attracts the interest of the searcher. The job title of an employee performing the same job function may differ from one company to another. Even the advertisement itself has a bearing on the type of position advertised.

3. Do you need to develop employees to work more effectively?

Developing the personality of employees is in the interest of every company, even if it costs time and money. Because training is a great help to develop the individual, strengthen the team, and clarify common goals, which helps the company to work more efficiently and achieve better results. Leadership training helps superiors to get to know people, improves communication with them, strengthens team spirit and helps to understand common goals and plans. Overall, better communication also makes work more effective.

\section{What does the effectiveness of training depend on?}

The effectiveness of the training is a determining factor in terms of the effectiveness with which the additional information obtained from the training and its integration into work processes contributes to the improvement and development of the previous situation.

In the further part of the research, we present the results, describe the operation of the selection and training processes within the company and analyze their effectiveness by evaluating the interviews. The company's goal is for properly selected employees to ensure that the firm remains long-term competitive and successfully adapts to the changing needs of the environment. The search profile of the given job and the needs, abilities and expectations of the applicant must be matched.

Today's accelerating changes in the global environment pose huge challenges to companies in the field. The most significant changes occur in digital economy and have had an enormous impact on the development of the consultancy industry (Poór et al. 2019). The selection of candidates that meet professional and competence requirements and the provision of staffing needs are of great importance. In accordance with the selection criteria, the candidate will be presented to the Head of the relevant department once the establishment plan has been received by the personnel department. Colleagues working within the company can also apply for other positions within the company with which the company supports the careers of employees. The condition for these applications is that the employee has at least 2 years of professional experience. The intention to transfer must be indicated in writing to the Personnel Department on a form drawn up for that purpose and signed by the Head of Unit. A personal interview will only take place after that. If the employee participates in a successful interview, the transferring and receiving department heads agree on the date of the transfer, which cannot be longer than 3 months after the successful interview. The pre-selection of the various applications received, the interviewing of the selected candidates, and then the finding and employment of the remaining candidates from the remaining candidates that best meet the requirements of the position provide the whole process.

\section{Results}

The selection process and recruitment itself are an essential point in the development of the company. It can be said to be the cornerstone, as the implementation of processes depends on employees. The competitiveness of a company requires goals, a well-structured strategy, plans, implementation programs, but all of this requires people, individuals who invent, create and execute them. That is why the foundation of success lies in people, in their abilities and attitudes. Throughout its long and successful career, the company has gained recognition and awareness among people as one of the most significant players in the Hungarian automotive industry. In the context of competitiveness, it is important to find the best possible people for open positions. What requires two things is the application of the law of large numbers and the establishment of high standards. The company displays and recruits people in plenty of places. Job fairs, university affiliate programs where you consciously apply personal persuasion tactics. Fig. 1. shows how 
people found out about job opportunities, so we get an idea of what the most effective appearances are.

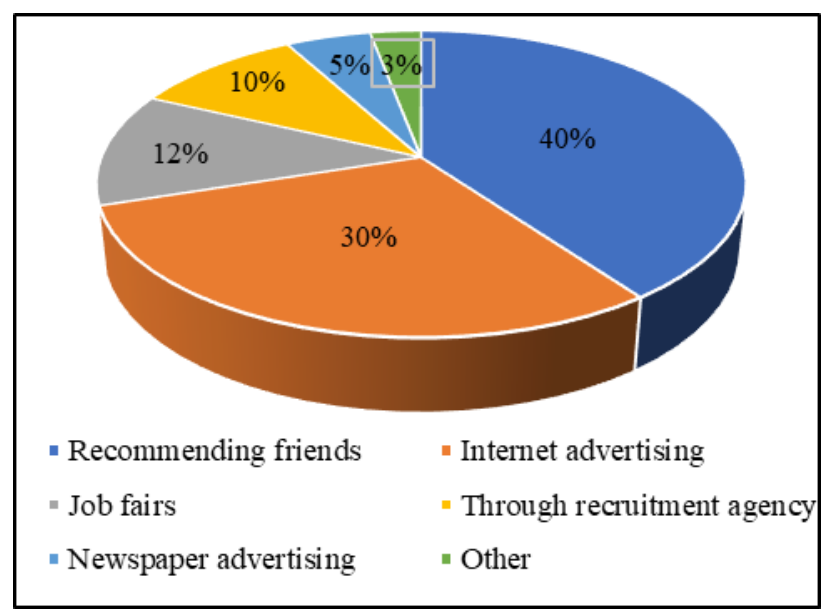

Fig. 1. Channels of job opportunities $(n=25)$ Source: authors' construction

The chart illustrates well that the greatest interest in job opportunities is achieved by the recommendation of acquaintances, namely this shows for the future that the company needs to build its strategy on the reference. It is clear from the chart that online job postings are also popular among applicants, as it can be said that this is the most easily accessible form of applying for a job. Job fair is the third most popular channel, making it more effective, because personal contact appears here. Communication is therefore a key element in ensuring that selection processes bring people to the company who, through their work, contribute to improving the company's competitiveness. Based on this conviction, we also examined what aroused the interest of individuals in each advertisement and conversation. The point is to raise awareness, of things that are attractive to young and older job seekers today. Fig. 2. shows which are the most attractive supply items today.

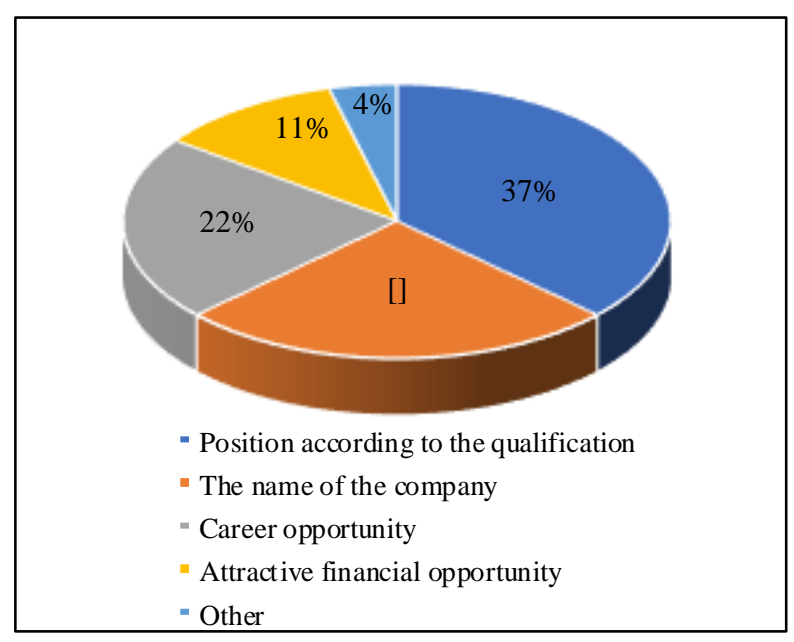

Fig. 2. The most attractive elements of advertisements $(n=25)$

Source: authors' construction
Of course, the more it is in line with a person's qualifications and experience, the more it will raise their interest. Applicants can move in a direction, looking primarily for ads that match their qualifications. Today, the name, profile and market position of the company are also very decisive, because from this people assume that they are applying for a job that is stable. Material factors are also important, as the income earned is important for everyone. On the other hand, there are other factors that may override this or may be more important than the financial benefit. Such is the increasingly popular "home office" option today, the accessibility of the company, the convenience aspects of the people. Standing on more than one foot alone is the foundation for later success, as being present in more places gives you more opportunities to find the most valuable people in the profession. Thus, recruitment as the first step in selection is the most important element, the strongest determining factor of competitiveness in terms of the selection process. From the pool of applicants, the company filters out those who are best suited to each position. It performs pre-screening by phone, you already select with this and only gives the best the opportunity to meet in person. The next essential point of selection is the job interview. The essence and success of a personal encounter is made up of several small elements that need to be addressed. Selection does not make a company competitive by organizing and conducting interviews, but by the quality at which it does so. The essence of competitiveness lies in how we are compared to others. Are we better than our competitors? Are we able to find the best, professionally trained, stable and balanced people?

Training results, examination of their effectiveness

In the following part we will get an answer to the efficiency of the trainings within the company. Processes alone are not enough, in addition to assessing needs and clarifying goals, the greatest emphasis is on implementation. Based on the responses received, we can say that $90 \%$ of people attach great importance to corporate training. There is a demand for it among the employees, they prefer the training programs of the company. You need to see how people feel about the importance of training, since such a program can be successful if employees are collaborative and open to professional development. We can make certain processes more efficient, thus raising the standard of quality, but overall, improving smaller processes will result in the company as a whole being able to grow, which will play a key role in maintaining competitiveness. The opinions of the respondents are illustrated in Fig. 3. 


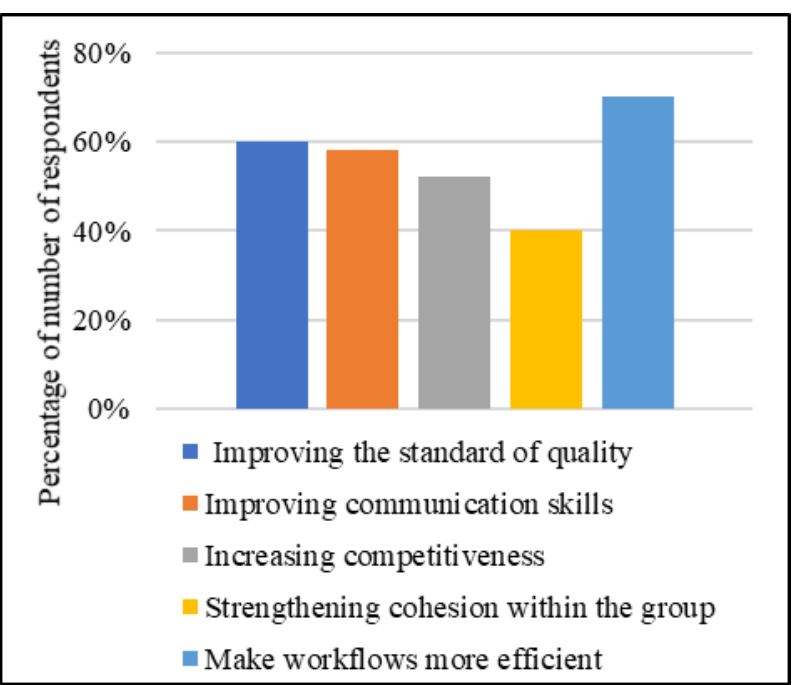

Fig. 3. The importance of staff development $(n=25)$ Source: authors' construction

We can see that the vast majority of respondents, more than $70 \%$, believe that staff development is needed primarily to make work processes more efficient. $60 \%$ think it is necessary to raise the standard of quality. From this, it can be concluded that employees believe these two factors are the most important for a company to get ahead in the market. This is an important starting point, as we see that the employee knows that training is indeed needed and knows what factors play a role in terms of competitiveness. Based on the above data, we can say that employees clearly see the most important elements of competitiveness, so their attitude to training will be positive, they will be able to cooperate. The primary thing is for the company to be purposeful, to know what it wants to achieve, and to steer training processes in that direction. As a large domestic company, it generates complex tasks. Accordingly, it provides diverse, multilayered training to its employees, as each area is endowed with different characteristics, plans and barriers. Needs are different, goals are different, and the organization sees this exactly and provides multiple types of training accordingly.

It is important to develop language trainings and computer skills. Due to the company's international relations system, knowledge of foreign languages is essential. The international relations enhance the company's competitiveness. In addition to communication in foreign languages, it is important to highlight training in corporate governance systems. Routine use of the SAP system facilitates the fast and precise implementation of processes, reduces the possibility of errors, improves the quality of work, thus making work more efficient in the long run.

As a result, the company as a whole is evolving. Properly oriented training does not work in itself. Success depends on several factors. In any case, the decisive factor is that the conduct of the trainings is onesided, only striving for the rapid transfer of knowledge, or communicative and two-sided. People need to be able to give feedback. The company is increasingly striving for this, which may be key in the future because it cannot ignore the issues raised by employees. The essential points of the trainings will be shown to us by their effectiveness.

Training will be effective and will contribute to competitiveness if it raises the standard of work processes (Fig. 4.). If the employee is up-to-date, accurate, wellinformed, has a better understanding of responsibilities, becomes more practical, the quality of his work improves, and at the same time he develops himself.

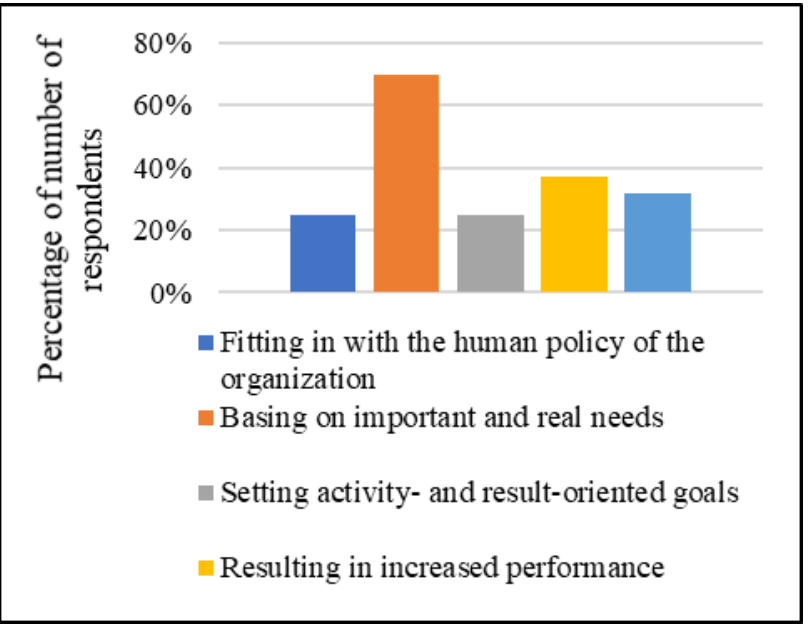

Fig. 4. What does the effectiveness of the training depend on? $(\mathrm{n}=25)$

Source: authors' construction

The majority of respondents, $70 \%$, say that training should be based on important and real needs in order to recoup the capital invested in training, while these figures are $37 \%$ and $32 \%$ for performance improvement and the continuous and permanent nature of training, respectively. Only $25 \%$ of respondents believe that training, activity and results-oriented goals are set, and only $20 \%$ believe that the effectiveness of education depends on the fit of the organization's human resources policy. For that reason, we can clearly state that it is only worthwhile for companies to invest significant sums in human capital training if there is a real demand for it and the company can capitalize on, thus increasing its competitiveness in the market.

\section{Conclusions}

Considering the research aspects according to which selection and training play a role in maintaining competitiveness, we can clearly say that when selecting an employee, a "search" process is started, which focuses on finding the most suitable employee for the given job, whose qualifications and professionalism allows it to engage in a company's rapidly evolving economic life. Due to continuous training, it will be an essential player in the company's processes and thus contribute to the preservation and continuous development of the competitive factors that appear in the competitive market. Based on the processing of the interviews, we can state that the company works with a well-thought-out, wellestablished selection and training system. We have to point out that most of the new employees who come into the organization are not hired by the company through the 
internet or job fairs, but through acquaintances who find out about the job opportunities, which in our opinion is a huge advantage over other multinational companies.

In terms of job vacancies, advertising forums should be better selected, the main thing of which is that the ad should be advertised based on the needs, namely personalized. It will not be of the same interest to a woman as to a man, a recent graduate, or just a leader. The economic difficulties caused by the pandemic indicate that companies are taking advantage of the situation. On the market demand side, people are more receptive because they are less able to choose between job opportunities. At the same time, it can be the best opportunity for a company to stand out and not follow the kind of behavior that the majority of companies have adopted today. Regarding training programs, in addition to the day-to-day work of employees, in order to remain competitive, they must meet the requirements dictated by the company, so they have to attend a number of trainings that do not always achieve the desired effect due to congestion.

Improving the effectiveness of these trainings could be reached by increasing the motivation of employees. In order to accomplish these goals, the company must create the opportunity for trainings to attain the greatest impact among employees, thus using this professional knowledge to contribute even more to the maintenance of organizational performance.

\section{References}

Adler, N. J., Ghadar, F. (1990). Strategic Human Resource management: a global perspective. In: Pieper, R. (ed.) Human Resource Management. An International Comparison. Walter de Gruyter. Berlin. 60-235. pp.

Agu, K. O., \& Fekete-Farkas, M. (2016). Creativity and Innovation Exploration: The Impact Of Cultural Diversity Of an Organization. Journal of Management, 28(1), 67-75

Aiginger, K., Landesmann, M. (2002). Competitive economic performance: the European view. Working Papers. No.179 Vienna.

Arthur, J. B. (1994). Effects of human resource systems on manufacturing performance and turnover. Academy of Management Review. Vol. 37. No. 4. 670-87. pp.

Beardwell, I., Holden, L. (1994). An Introduction to Human Resource Management. In Beardwell, I. - Holden, L. (eds.): Human Resource Management: A Contempoxrary Perspective, Singapore. Pitman Publishing. 4-10. pp.

Becker, B. E., Huselid, M. A. (2006). Strategic Human Resource Management: Where Do We Go From Here? Journal of Management. Vol. 32. No. 6. 898-925. pp.

Borisov, I., Vinogradov, S. (2020). The Effect of Collaboration Oriented Managerial Environment on Employee Job Satisfaction VADYBA Journal of Management, 35(2),3948.

Boxall, P., Purcell, J. (2000). Strategic human resource management: where have we come from and where should we be going? International Journal of Management Reviews. Vol. 2. Issue 2. 183-203. pp.

Bratton, J., Gold, J. (1994). Human Resource Management Theory and Practice. Macmillan. London.

Brewster, C. (2002). Human Resource Practices in Multinational Companies. Blackwell, Oxford. 140. p.

Brewster, C. (2007). Comparative HRM: European views and perspectives. International Journal of Human Resource Management. Vol. 18: No. 5. May 769 - 787 pp.
Brewster, C., Morley, M., Buciuniene, I. (2010). The reality of human resource management in Central and Eastern Europe. Baltic Journal of Management. (5): 145-155. pp

Chang, W. J. A., Huang, T., C. (2005). Relationship between strategic human resource management and firm performance. A contingency perspective. International Journal of Manpower. Vol. 26. No. 5. 434-449. pp.

Chikán, A. (2017). Vállalatgazdaságtan. Budapest, Aula Kiadó

Chikán, A., Czakó, E. (2009). Versenyben a világgal. Vállalataink versenyképessége az új évezred küszöbén. Akadémia Kiadó. Budapest.

Choi, S., \& Rainey, H. G. (2013). Organizational Fairness and Diversity Management in Public Organizations: Does Fairness Matter in Managing Diversity? Review of Public Personnel Administration, 34(4), 307-331. doi:10.1177/0734371X13486489

Csath, M. (2010). Versenyképesség-menedzsment. Budapest, Nemzeti Tankönyvkiadó.

Csath, M. (2004). Stratégiai tervezés és vezetés a 21. században.

Cohen, D., Prusak L. (2001). In Good Company. How Social capital makes organizations work. Harvard Business School Press. Boston.

Collis, D.J., Montgomery, C., A. (2008). Versengés az erőforrások terén. Harvard Business Review. Magyar Kiadás. 2008. December.

De Silva, S. (1997). Human Resources Development for Competitiveness: Priority of Employers. Turin. Paper presented at the ILO Workshop on Employers' Organizations.

Feurer, R., Chaharbaghi, K. (1994). Definig competitiveness, a holistic approach management decision, Vol. 32 Iss: 2. p. 49-58.

Gallie, D., Zhou, Y. (2013). Work organisation and employee involvement in Europe [Report] Publications Office of the European Union, Luxembourg, 2013.

Glaister, A. J. (2014). HR outsourcing: the impact on HR role, competency development and relationships. Human Resource Management Journal, 24 (2), 211-226

Gmür, M., Thommen, J., P. (2007). Human Resource Management. Versus. München. 50. p

Gooderham, P., Nordhaug, O. (2010). One European model of HRM? Cranet empirical contributions. Human Resource Management Review, (21): 27-36. pp.

Hodges, J. (2017): Consultancy, organization development and change, London: KoganPage.

Lawler, E.E. and Boudreau, W.J. (2018). Effective human resource management, A global analysis. Los Angeles: Stanford University

Poór, J. (2013). Az emberierőforrás-gazdálkodás átalakulása a nemzetközi cégek leányvállalatainál Magyarországon és a kelet-európai régióban. Közgazdasági Szemle. LX. ÉVF: JANUÁR. 64-89. pp.

Poór J., Farkas F., Engle, A., D. (eds.) (2012). Human Resource Management Issues and Challenges in Foreign Owned Companies: Central and Eastern Europe. Faculty of Economics. Janos Selye University, Komárno

Poór, J., Csapó, I., Kovács, I., Karoliny, Zs., Khaloud, A., Barasic, F. A., Sanders J. E. (2019). Trends in the management consulting of HRM services in the light of empirical researches. VADYBA Journal of Management, 34 (1), 47-58

Purcell, J., Kinnie, K., Hutchinson, R. B., Swart, J. (2003). People and Performance: How people management impacts on organisational performance. CIPD. London.

Schuler, R. S. (2000). Internationalization of human resource management. Journal of International Management. 2000/6. 239-260. pp. 
Szewczak, K., Woźniak, W. (2019). Changes of the factors affecting the quality of life VADYBA Journal of Management, 35(2), 61-66
Wolff, F., Schmitt, K., Hochfeld, C. (2007). Competitiveness, innovation and sustainability - clarifying the concepts and their interrelations. ÖkoInstitute e.V. Berlin. July 200

Endre SZABÓ, PhD candidate of Management and Business Administration Doctoral School in Hungarian University of Agricultural and Life Sciences, Field of scientific research: business management, competitive management, Address: H-2100 Gödöllő, Páter Károly u. 1, Hungary, Phone. +36 70 335-6063. E-mail: endi.szabo@gmail.com

Katinka BAJKAI-TÓTH PhD candidate of Management and Business Administration Doctoral School in Hungarian University of Agricultural and Life Sciences, Field of scientific research: human resource management, Address: H-2100 Gödöllö, Páter Károly u. 1, Hungary, Phone. +36 20 574-4760. E-mail: bajkai.toth.katinka@gmail.com

Ildikó RUDNÁK PhD, associate professor at Hungarian University of Agricultural and Life Sciences, Institute of Social Sciences, Field of scientific research: multiculturalism communication organizational culture training - coaching culture shock adaptation competences. Address: H-2100 Gödöllö, Páter Károly u. 1, Hungary, Phone. +36 30 212-7545. E-mail: Rudnak.Ildiko@uni-mate.hu

Róbert MAGDA prof., PhD, is a professor, Head of Economics Department at Hungarian University of Agriculture and Life Sciences Institute of Economics and an extra ordinary professor at School of Management Sciences Faculty of Economic and Management Sciences, North-West University, South Africa. Field of scientific research: management, efficiency of natural resource utilization, economy of rural areas. Address: H-2100 Gödöllö, Páter Károly u. 1, Hungary, Phone. +36 20 932-1322. E-mail: magda.robert@uni-mate.hu 